\title{
Exfoliation Syndrome in Egypt: Prevalence and Association with Cataract in a Large Cohort
}

\author{
Bassem Fayez Aziz (D) - Amr Ismail Elawamry • Maged Maher Roshdy • \\ Caroline Atef Tawfik
}

Received: July 27, 2021 / Accepted: September 7, 2021 / Published online: September 27, 2021

(C) The Author(s) 2021

\section{ABSTRACT}

Introduction: Exfoliation syndrome is an agerelated disease leading to ocular and systemic complications. We aimed to evaluate the prevalence of exfoliation syndrome (XFS) in Egypt and its association with cataract as one of its comorbidities.

Methods: In a retrospective, hospital-based study, 155,032 Egyptians aged over 40 years from all 27 Egyptian governorates were evaluated for the prevalence of XFS and cataract in the period between January 2015 and June 2020.

Results: A total of $2448(1.6 \%)$ of the studied subjects had XFS. Their mean age was $71.2 \pm 9.62$ years which was significantly higher than those of subjects with no XFS. Men comprised 1348 (55.1\%) of those diagnosed with XFS and this association was statistically significant (OR 1.57, 95\% CI 1.45-1.70).

B. F. Aziz ( $\square)$ • A. I. Elawamry · M. M. Roshdy • C. A. Tawfik

Faculty of Medicine, Ain Shams University, Cairo, Egypt

e-mail: b_fayez@med.asu.edu.eg

B. F. Aziz - A. I. Elawamry · M. M. Roshdy .

C. A. Tawfik

Watany Eye Hospital, Cairo, Egypt

B. F. Aziz

Bassem Fayez Clinic, 50 Al Khalifa Al Mamoun St., Roxy, Heliopolis, Cairo, Egypt
Considering the ratio between subjects in our cohort from each region and its real population, the overall corrected prevalence in Egypt was 4.49\% (Territorial regions 6.89\%, Upper Egypt $5.51 \%$, Lower Egypt $4.38 \%$, and Greater Cairo $3.29 \%)$. Among all subjects with XFS, cataract was found in 2150 subjects $(87.8 \%)$ and XFS represented $6.4 \%$ of all subjects diagnosed with cataract in our cohort $(n=33,610)$. Among subjects with no cataract $(n=121,422), 298$ subjects had XFS (OR 0.04, 95\% CI 0.03-0.04). Conclusion: Egypt has a moderate XFS prevalence compared to other countries. There is a strong association between XFS and cataract, and XFS was more common in elderly males. The results can be explained by differences in diet, ethnicity, climate, and maybe other factors.

\section{PLAIN LANGUAGE SUMMARY}

Exfoliation syndrome (XFS) is an age-related disease characterized by the deposition of distinctive material in many eye and systemic tissues, with resultant eye (lens opacities, chronic rise in eye pressure, and more frequent surgical complications during lens surgeries) and systemic health implications (hearing loss and cardiovascular diseases). It is a universal disease that occurs in virtually all countries and whose percentage among individuals varies from one 
country to another, hence the importance of studies determining its percentage. We conducted our study on a large group of individuals encompassing more than 155,000 individuals aged over 40 years in the period between January 2015 and June 2020, to determine how frequent it is in Egypt and its different regions, and determine its common associations. Overall, it had moderate frequency, most commonly found among older subjects, men, those residing in territorial areas of Egypt as well as those having cataracts and lens opacities. Given Egypt's unique geographical location being a transcontinental country (Afro-Asian), and belonging to Middle Eastern as well as Mediterranean countries, our results can be extrapolated to other neighboring countries and are not exclusive to Egypt. Studying this prevalence will give insights into risk factors for the disease that could possibly be modified, as well as determining the population at risk to help stakeholders to design effective screening programs.

Keywords: Cataract; Egypt; Exfoliation syndrome; Prevalence

\section{Key Summary Points}

Why carry out this study?

Exfoliation syndrome (XFS) is a universal disease, but its prevalence varies from one population to another with different geographical and ethnic background.

We evaluated the prevalence of XFS in Egypt with its different regions and governorates and determined its association with cataract in the population aged over 40 years.

\section{What was learned from the study?}

Overall prevalence of XFS in Egypt was moderate (4.49\%). It was more commonly found in older ages, males, those residing in territorial regions as well as those having cataract.
Identifying prevalence among different countries may help in the search for etiological factors, and results can be extrapolated to neighboring countries aiding in designing effective screening programs for the at-risk population.

\section{INTRODUCTION}

Exfoliation syndrome (XFS) is an age-related systemic disease of the extracellular matrix, characterized by the deposition of distinctive fibrillar material in many ocular and extraocular tissues [1]. It has been reported that XFS has associations with sensorineural hearing loss, hyperhomocysteinemia [2], and systemic vascular diseases such as hypertension, angina pectoris, myocardial infarction, stroke, and abdominal aortic aneurysm [3].

Lindberg first described XFS in a Finnish population in 1917 following his observation of the presence of bluish-gray deposits on the pupillary border of $50 \%$ of his patients with chronic glaucoma [4]. Historically, XFS has been thought to affect principally North European and the Scandinavian population [5]. However, it has been proven to occur virtually in any area of the world, yet its prevalence varies among different ethnic groups and geographical regions [6].

Historically, the epidemiology of XFS is among the most controversial subjects in the literature, and many studies on the prevalence of XFS in various populations with different ethnic backgrounds exist [7]. The lowest prevalence is recorded in Eskimos and Inuits from Greenland (0\%), whereas the highest prevalence is reported among Finns (22.4\%) [8], Swedes (23\%) [9], Icelanders (30\%) [10], and Navajo Indians (38\%) [11].

As the true prevalence of XFS in our country, Egypt, and its different regions, is not yet well known, we conducted this study to investigate XFS prevalence and association with cataract, as one of the most common comorbidities, in Egypt and different Egyptian governorates. 


\section{METHODS}

A retrospective hospital-based study was conducted in both branches of a high-volume ophthalmology hospital with a catchment area from all over Egypt-Watany Eye Hospital, Cairo, Egypt. The electronic medical records of the hospital were filtered for all subjects over the age of 40 years who had visited the hospital for comprehensive ophthalmological examination owing to any eye complaint during the period between January 2015 and June 2020 .

All the subjects underwent the routine complete undilated and dilated ophthalmological examination. Tropicamide $1 \%$ eye drops were usually used once or twice. The diagnosis of XFS was definite if at least one eye showed the following: the pupillary margin had precipitations of grayish dandruff-like material and the lens surface showed a whitish central coating whose diameter was slightly less than the normal pupillary diameter, or if the lens periphery showed a whitish coating bordered anteriorly by a darker ring-like region. This darker, ring-like region corresponded to the region of the pupillary margin movements over the lens surface [1]. The patient was considered cataractous if they had cortical, nuclear, or posterior subcapsular lens opacity in either eye. We excluded subjects with bilateral aphakia or pseudophakia on presentation as the diagnosis of XFS in such eyes is markedly less accurate. Moreover, eyes with congenital, developmental, traumatic, and complicated cataracts were also excluded. For each subject, the following data were collected: age, sex, the governorate of residence, presence of XFS, and presence of cataract. The governorates were grouped into the main four regions of Egypt: Greater Cairo, Upper Egypt, Lower Egypt, and finally the Suez Canal and territorial region (Fig. 1) [12].

Since not all the governorates were equally represented in our sample, the prevalence in each region cannot be simply calculated as the average of those of the governorates included in this region. Therefore, we opted to calculate the corrected prevalence rate among the four regions.

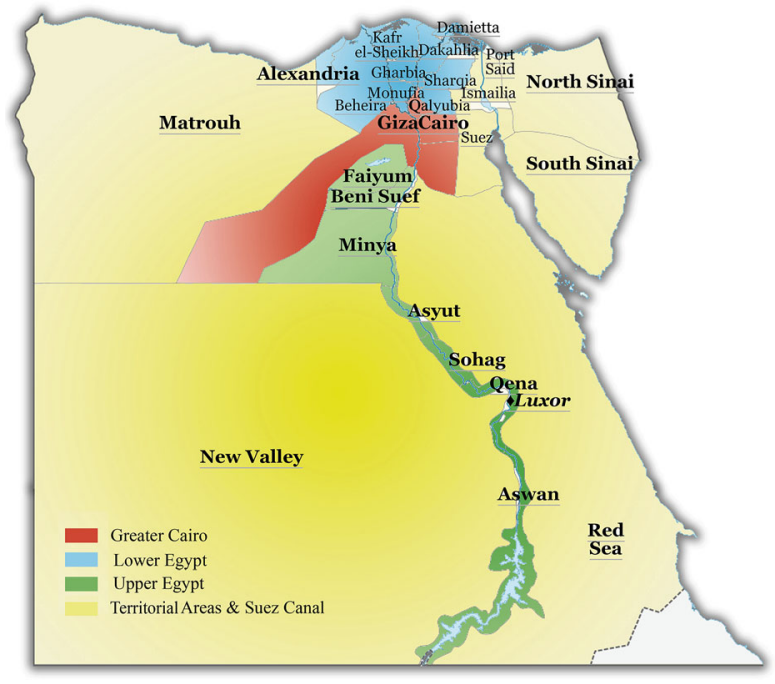

Fig. 1 Four main Egyptian regions [12]

The XFS prevalence in subjects that presented to our hospital from each governorate equals the number of subjects found to have XFS from this governorate divided by the total number of subjects that presented from the same governorate.

The estimated number of subjects with XFS in each governorate equals the XFS prevalence in subjects that presented to our hospital from each governorate multiplied by the total number of subjects aged over 40 years living in that governorate.

The corrected XFS prevalence in each region equals the sum of estimated subjects with XFS in all the governorates of the region divided by the region population over 40 years.

The population of each governorate over 40 years was extracted from the results of the Central Agency for Public Mobilization and Statistics (CAPMAS) 2017 census which was within the study period [13].

The research protocol has been submitted to the Ethics Committee of Watany Research and Development Center (WRDC), Cairo, Egypt, and was found to agree with the tenets of the Declaration of Helsinki. The Ethics Committee of WRDC waived the ethical approval and the need to obtain patient consent because of the retrospective nature of the study. 


\section{Statistical Analysis}

The statistical analysis was performed using MedCalc Statistical Software version 19.4 (MedCalc Software Ltd, Ostend, Belgium). Means, standard deviations (SDs), odds ratios (OR), and 95\% confidence intervals (CI) were calculated. A $p$ value of less than 0.05 , measured by Welch's test, indicated statistical significance.

\section{RESULTS}

A total of 155,032 indigenous Egyptians aged over 40 years from all the 27 Egyptian governorates were included. Of them, 2448 had XFS. The mean age of studied subjects was 59.5 years (SD 11.9) (median 59, range 40-100). The mean age of subjects with XFS was 71.2 years (SD 9.62) (median 71, range 41-100) which was significantly higher than those of subjects with no XFS, 59.3 years (SD 11.9) (median 59, range 40-99), $(P<0.0001)$. This was further confirmed by the increase in OR of XFS with age (Table 1).

Although $86,840(56.0 \%)$ of the studied patients were female, 1348 (55.1\%) of those diagnosed with XFS were male. The association between XFS and male sex was statistically significant (OR 1.57, 95\% CI 1.45-1.70).

Regarding the geographical distribution of the studied subjects among the main four regions in Egypt, 139,701 subjects (90.1\% of the cohort) were from Greater Cairo, 10,244 (6.6\%) from Upper Egypt, 2784 (1.8\%) from Suez Canal and territorial areas, and 2303 (1.5\%) from Lower Egypt (Table 2).

In our study, Cairo governorate had the highest number of studied subjects ( $n=133,968)$, representing $86.4 \%$ of the sample. This was follwed by Giza governorate with 4091 subjects $(2.6 \%)$, then Minya governorate with $2846(1.8 \%)$, and lastly Sohag governorate with 2089 (1.3\%) (Table 2).

The overall prevalence of XFS in our cohort was $1.6 \%$. However, considering the ratio between subjects in the cohort from the four regions and the real population of each region, the overall corrected prevalence in Egypt was $4.49 \%$. The corrected prevalence was highest among the inhabitants of the Suez Canal and territorial areas, accounting for $6.89 \%$, followed by Upper Egypt with 5.51\%, Lower Egypt with $4.38 \%$, and least among subjects from Greater Cairo with 3.29\% (Table 2).

Among all subjects, cataract was found in 33,610 subjects $(21.7 \%)$. It was present in 2150 $(87.8 \%)$ of the subjects diagnosed with XFS $(n=2448)$ but in only $31,460(20.3 \%)$ of the subjects with no XFS $(n=152,584)$. The OR of cataract in XFS was 27.77 (95\% CI 24.59-31.38).

On the other hand, XFS was found in 2150 subjects $(6.4 \%)$ of those diagnosed with cataract $(n=33,610)$ and in 298 subjects $(0.24 \%)$ of those without cataract $(n=121,422)$, (OR 0.04, 95\% CI 0.03-0.04). This confirmed the strong association between XFS and cataract.

Table 1 Prevalence and odds ratio of XFS in each age group

\begin{tabular}{lcclll}
\hline Age group (years) & \multicolumn{2}{l}{ Total number of subjects } & \multicolumn{2}{l}{ Patients with XFS } \\
\cline { 3 - 6 } & & Number & $\%$ & Odds ratio & Odds ratio 95\% CI \\
\hline $40-49$ & 38,898 & 48 & 0.12 & 0.058 & $0.044-0.078$ \\
$50-59$ & 38,763 & 221 & 0.57 & 0.293 & $0.256-0.337$ \\
$60-69$ & 43,174 & 796 & 1.84 & 1.253 & $1.151-1.365$ \\
$70-79$ & 26,088 & 896 & 3.43 & 2.919 & $2.686-3.173$ \\
$80-89$ & 7359 & 419 & 5.7 & 4.333 & $3.891-4.828$ \\
$90-100$ & 750 & 68 & 9.06 & 6.364 & $4.944-8.192$ \\
\hline
\end{tabular}

$C I$ confidence interval 
Table 2 Prevalence in the sample and corrected prevalence of different Egyptian regions

\begin{tabular}{|c|c|c|c|c|c|c|c|c|}
\hline \multirow[t]{2}{*}{ Region } & \multirow[t]{2}{*}{ Governorate } & \multicolumn{2}{|c|}{ XFS cases } & \multicolumn{2}{|c|}{$\begin{array}{l}\text { All studied } \\
\text { subjects in the } \\
\text { cohort }\end{array}$} & \multirow{2}{*}{$\begin{array}{l}\text { Estimated } \\
\text { number of } \\
\text { subjects with } \\
\text { XFS }\end{array}$} & \multirow[t]{2}{*}{$\begin{array}{l}\text { Actual } \\
\text { population }>40 \text { years }\end{array}$} & \multirow{2}{*}{$\begin{array}{l}\text { Corrected } \\
\text { prevalence of } \\
\text { XFS in each } \\
\text { region }\end{array}$} \\
\hline & & $\bar{N}$ & $\%$ & $\bar{N}$ & $\%$ & & & \\
\hline \multirow{4}{*}{$\begin{array}{r}\text { Greater } \\
\text { Cairo }\end{array}$} & Cairo & 1343 & 54.8 & 133,968 & 86.4 & 28,725 & $2,865,355$ & \\
\hline & Giza & 253 & 10.3 & 4091 & 2.6 & 120,522 & $1,948,834$ & \\
\hline & Qalyubia & 65 & 2.65 & 1642 & 1.1 & 52,799 & $1,333,785$ & \\
\hline & Subtotal & 1661 & 67.9 & 139,701 & 90.1 & 202,046 & $6,147,974$ & $3.29 \%$ \\
\hline \multirow{9}{*}{$\begin{array}{l}\text { Lower } \\
\text { Egypt }\end{array}$} & Alexandria & 11 & 0.44 & 344 & 0.2 & 47,784 & $1,494,325$ & \\
\hline & Beheira & 6 & 0.24 & 88 & 0.06 & 101,269 & $1,485,282$ & \\
\hline & Damietta & 0 & Zero & 74 & 0.05 & - & 386,566 & \\
\hline & Dakahlia & 11 & 0.44 & 304 & 0.2 & 61,464 & $1,698,636$ & \\
\hline & Gharbia & 14 & 0.57 & 265 & 0.2 & 71,402 & $1,351,537$ & \\
\hline & $\begin{array}{l}\text { Kafr El- } \\
\text { Sheikh }\end{array}$ & 0 & 0 & 43 & 0.03 & - & 852,851 & \\
\hline & Monufia & 23 & 0.94 & 413 & 0.3 & 59,149 & $1,062,113$ & \\
\hline & Sharqia & 45 & 1.8 & 772 & 0.5 & 97,741 & $1,676,794$ & \\
\hline & Subtotal & 110 & 4.49 & 2303 & 1.5 & 438,809 & $10,008,104$ & $4.38 \%$ \\
\hline \multirow{9}{*}{$\begin{array}{l}\text { Suez Canal } \\
\text { and } \\
\text { territorial } \\
\text { areas }\end{array}$} & Ismailia & 41 & 1.67 & 491 & 0.3 & 25,637 & 307,020 & \\
\hline & Matrouh & 0 & 0 & 21 & 0.01 & - & 76,459 & \\
\hline & North Sinai & 16 & 0.65 & 155 & 0.1 & 9626 & 93,256 & \\
\hline & Port Said & 13 & 0.53 & 511 & 0.3 & 5826 & 229,017 & \\
\hline & Red Sea & 12 & 0.5 & 618 & 0.4 & 1486 & 76,536 & \\
\hline & South Sinai & 6 & 0.24 & 63 & 0.04 & 1957 & 20,552 & \\
\hline & Suez & 37 & 1.51 & 906 & 0.6 & 7498 & 18,3591 & \\
\hline & New Valley & 6 & 0.24 & 19 & 0.01 & 20,359 & 64,470 & \\
\hline & Subtotal & 131 & 5.35 & 2784 & 1.8 & 72,389 & $1,050,901$ & $6.89 \%$ \\
\hline
\end{tabular}


Table 2 continued

\begin{tabular}{|c|c|c|c|c|c|c|c|c|}
\hline \multirow[t]{2}{*}{ Region } & \multirow[t]{2}{*}{ Governorate } & \multicolumn{2}{|c|}{ XFS cases } & \multicolumn{2}{|c|}{$\begin{array}{l}\text { All studied } \\
\text { subjects in the } \\
\text { cohort }\end{array}$} & \multirow{2}{*}{$\begin{array}{l}\text { Estimated } \\
\text { number of } \\
\text { subjects with } \\
\text { XFS }\end{array}$} & \multirow[t]{2}{*}{$\begin{array}{l}\text { Actual } \\
\text { population }>40 \text { years }\end{array}$} & \multirow{2}{*}{$\begin{array}{l}\text { Corrected } \\
\text { prevalence of } \\
\text { XFS in each } \\
\text { region }\end{array}$} \\
\hline & & $N$ & $\%$ & $N$ & $\%$ & & & \\
\hline \multirow{9}{*}{$\begin{array}{l}\text { Upper } \\
\text { Egypt }\end{array}$} & Beni Suef & 30 & 1.22 & 558 & 0.4 & 35,200 & 654,715 & \\
\hline & Asyut & 100 & 4.1 & 1428 & 0.9 & 65,617 & 937,017 & \\
\hline & Aswan & 47 & 1.92 & 519 & 0.3 & 32,013 & 353,505 & \\
\hline & Faiyum & 28 & 1.14 & 634 & 0.4 & 31,133 & 704,933 & \\
\hline & Luxor & 36 & 1.47 & 499 & 0.3 & 22,486 & 311,685 & \\
\hline & Minya & 118 & 4.82 & 2846 & 1.8 & 49,087 & $1,183,912$ & \\
\hline & Qena & 57 & 2.33 & 1671 & 1.1 & 24,207 & 709,635 & \\
\hline & Sohag & 130 & 5.31 & 2089 & 1.3 & 65,560 & $1,053,493$ & \\
\hline & Subtotal & 546 & 22.3 & 10,244 & 6.6 & 325,303 & $5,908,895$ & $5.51 \%$ \\
\hline Total & & 2448 & 100 & 155,032 & 100 & $1,038,547$ & $23,115,874$ & $4.49 \%$ \\
\hline
\end{tabular}

Regarding the other associated factors, XFS was most likely to be found in men (Table 3 ).

\section{DISCUSSION}

The reasons speculated to be behind marked the variability in prevalence rates of XFS even within the same country or region can be multifactorial: ethnic differences, age, gender distribution, genetic predisposition of the population under study, their geographical distribution with different climatic conditions, dietary habits, the variable clinical criteria used for diagnosis, the examiner's experience in detecting early stages of the disease on routine examination without pupillary examination, and the difficulty in detection of lenticular signs of XFS in patients with existing cataract [7]. Therefore, we opted for a large sample to dilute some individual factors and to reach a more realistic prevalence estimate.

To the best of our knowledge, the only previous estimate for XFS cases in Egypt was based on a cohort from Upper Egypt only [14]. We assumed that the prevalence may differ from one region to another; hence, we conducted this study with a much larger sample from every governorate in Egypt. However, Greater Cairo residents represented $90.1 \%$ of our sample, as it is the most populated region in Egypt as it includes the most populated governorate, Cairo; moreover, both branches of our hospital are located in Cairo. Meanwhile, subjects from the Upper Egypt region represented only $6.6 \%$. Nevertheless, we included in our cohort more cases than those included in the Upper Egypt study.

We found the corrected prevalence of XFS to be $4.49 \%$ in Egyptians over 40 years of age. Our corrected prevalence of XFS in Upper Egypt $(5.51 \%)$ was slightly higher than that estimated by Shazly et al. in a smaller cohort from Upper Egypt (4.1\%) [14]. We believe that the difference in prevalence is related to climate conditions or dietary habits, with less folate intake in Upper Egypt [15]. Lower risk of XFS is associated with higher total folate intake, supporting a possible causal effect secondary to increased plasma homocysteine levels [16] which is a wellstudied potential biomarker for XFS [17]. 
Table 3 Odds ratio and 95\% CI of factors associated with XFS

\begin{tabular}{|c|c|c|c|c|c|}
\hline & $\begin{array}{l}\text { Total subjects } \\
N=155,032\end{array}$ & $\begin{array}{l}\text { XFS group } \\
N=2448\end{array}$ & $\begin{array}{l}\text { Non-XFS group } \\
N=152,584\end{array}$ & OR & 95\% CI \\
\hline \multicolumn{6}{|l|}{ Cataract } \\
\hline Present & 33,610 & 2150 & 31,460 & 27.78 & $24.59-31.38$ \\
\hline Absent & 121,422 & 298 & 121,124 & & \\
\hline \multicolumn{6}{|l|}{ Upper Egypt } \\
\hline Resident & 10,244 & 546 & 9698 & 4.23 & $3.84-4.66$ \\
\hline Non-resident & 144,788 & 1902 & 142,886 & & \\
\hline \multicolumn{6}{|l|}{ Lower Egypt } \\
\hline Resident & 2303 & 110 & 2193 & 3.52 & $2.89-4.29$ \\
\hline Non-resident & 152,729 & 2338 & 150,391 & & \\
\hline \multicolumn{6}{|c|}{ Territorial regions and Suez Canal } \\
\hline Resident & 2784 & 131 & 2653 & 3.19 & $2.66-3.83$ \\
\hline Non-resident & 152,248 & 2317 & 149,931 & & \\
\hline \multicolumn{6}{|l|}{ Gender } \\
\hline Male & 68,192 & 1348 & 66,844 & 1.57 & $1.45-1.70$ \\
\hline Female & 86,840 & 1100 & 85,740 & & \\
\hline
\end{tabular}

We compared our XFS prevalence to those of neighboring countries sharing similar geographical features, ethnic backgrounds, climatic conditions, diet, and lifestyle, namely the Mediterranean and Middle Eastern countries. Table 4 shows the different prevalence rates from studies involving subjects attending general ophthalmic clinics in these countries.

Among Mediterranean countries, the prevalence rate we calculated was comparable to those of Croatia (3.6\%) [18], Salnés Eye Study (6.5\%) [19], Central Anatolia (5.7\%) [20], Eskisehir of Turkey (5.0\%) [21], and Eastern Mediterranean of Turkey (7.2\%) [22]. However, higher prevalence rates were detected in Greece $[23,24]$ with the highest reported rate of $24.3 \%$ among the northwest population of Epirus [25], northeast and northwest regions of Spain (13.2 and $18.9 \%$, respectively) [26, 27], Tunisia (12.5\%) [28], and Black Sea region of Turkey $(12.2 \%)$ [29]. This could be attributed to true factors we could not account for or to the less accurate estimation by relatively small sample size. Even in the largest of them, it was about $1 / 28$ th of our cohort.

Among other Middle Eastern countries, our prevalence rate was higher than prevalence rates of northeast Iran (0.46\%) [30] but it was aligned with a recent study from a tertiary eye center in Jordan (4.9\%) [31] and Saudi Arabia (3.5\%) [32]. Yet it was lower than those of Central Iran (13.1\%) [33], Iraq (29\%) [34], and Yemen (18\%) [35]. This is probably related to two facts; first, the larger sample size of the studies that aligned with our results, and second, the proximity of Egypt to the aforementioned countries (Saudi Arabia and Jordan) latitude-wise, where all are more or less surrounding the $30^{\circ} \mathrm{N}$. This fact is associated with almost the same hazard of solar radiation [36].

The age-dependent nature of XFS has been established beyond doubt [7]. For example, in the Reykjavik Eye Study examining the prevalence of XFS in Iceland, the prevalence increased from $2.5 \%$ in those aged $50-59$ years to $40.6 \%$ in those aged 80 years or over, 
Table 4 Summary of studies on XFS prevalence in the Mediterranean and Middle Eastern countries in patients attending ophthalmological clinics

\begin{tabular}{|c|c|c|c|c|}
\hline Region & Country & Sample size $(n)$ & Age (years) & Prevalence (\%) \\
\hline \multirow[t]{15}{*}{ Mediterranean } & Croatia $[18]$ & 5349 & $\geq 40$ & 3.6 \\
\hline & \multicolumn{4}{|l|}{ Greece } \\
\hline & Crete [23] & 777 & $\geq 40$ & 16.1 \\
\hline & Northwest [25] & 700 & $\geq 50$ & 24.3 \\
\hline & Thessaloniki [24] & 2261 & $\geq 60$ & 11.9 \\
\hline & \multicolumn{4}{|l|}{ Spain } \\
\hline & Northeast [26] & 2342 & $\geq 60$ & 13.2 \\
\hline & Northwest [27] & 850 & $\geq 60$ & 18.9 \\
\hline & Salnés [19] & 1155 & $\geq 40$ & 6.5 \\
\hline & Tunisia [28] & 127 & $\geq 50$ & 12.5 \\
\hline & \multicolumn{4}{|l|}{ Turkey } \\
\hline & Central Anatolia [20] & 1107 & $\geq 40$ & 5.7 \\
\hline & Black Sea [29] & 831 & $\geq 45$ & 12.2 \\
\hline & Eastern Mediterranean [22] & 1356 & $\geq 40$ & 7.2 \\
\hline & Eskisehir [21] & 2356 & $\geq 40$ & 5.0 \\
\hline \multirow[t]{8}{*}{ Middle East } & Upper Egypt [14] & 7738 & $\geq 40$ & 4.1 \\
\hline & \multicolumn{4}{|l|}{ Iran } \\
\hline & Central [33] & 405 & $40-91$ & 13.1 \\
\hline & Northeast [30] & 519 & $45-69$ & 0.46 \\
\hline & Iraq [34] & 252 & $\geq 55$ & 29 \\
\hline & Jordan [31] & 1975 & $\geq 50$ & 4.9 \\
\hline & Saudi Arabia [32] & 1967 & $\geq 50$ & 3.5 \\
\hline & Yemen [35] & 2000 & $\geq 40$ & 18.0 \\
\hline
\end{tabular}

exhibiting a more than 16 -fold rise in prevalence [37]. We found a similar trend in our study where the prevalence increased from $0.12 \%$ in those aged $40-49$ years to $9.06 \%$ in those aged 90 years or over, with a marked rise in OR as shown in Table 1.

The reviewed studies reporting XFS prevalence varied in their inclusion criteria regarding age. Our study aimed to include the largest possible age group and so we included all those over 40 years of age to avoid missing such an important category of patients with significant findings and to detect XFS as it begins. We recommend including this wide age group in future studies aiming to investigate XFS prevalence rates.

Regarding gender, there is conflicting data on gender predilection for XFS in the literature. Many studies $[9,38]$ reported a slightly higher XFS prevalence in women, whereas others reported the opposite; mainly in southern Europe like Spain [39], Turkey [22], and Mexico 
[40]. Our study showed preponderance for men, which could be attributed to the currently adopted recommendation of folate intake for women in the child-bearing period in our country which was not the case in studies done years or decades ago leading to different outcomes.

In our study, we detected a prevalence rate of XFS of $6.4 \%$ among those with cataract, as opposed to only $0.24 \%$ in those without cataract. These results highlight a strong association between XFS and cataract and emphasize the need to examine cataract cases meticulously searching for XFS owing to its operative and postoperative implications. This association has been long recognized and investigated. Forsius reported variable prevalence rates of XFS among the cataract cohort ranging from $0.3 \%$ in Poland, $3.5 \%$ in France, $18 \%$ in Norway, and $33 \%$ in Finland [5]. Furthermore, among all our patients with XFS $(n=2448)$, cataract was found in 2150 of them (87.8\%). Even though a few studies found no causal relationship [41], a proposed hypothesis for this strong association is that XFS can promote ischemia of ocular tissues as well as defective antioxidant defense mechanisms that in turn could alter iris vasculature and blood-aqueous barrier. Thereby, the lens metabolism could be negatively affected with resultant cataract formation [42].
In comparison to the other Mediterranean and Middle Eastern countries (Table 5), our result regarding the prevalence of XFS in patients with cataract $(6.4 \%)$ was comparable to Turkey [43] and Jordan [44] (11\% and 10.3\%, respectively) but much lower than the rest of the studies which all reported rates of $20 \%$ or more. This could be attributed to significantly older populations studied than in our study, as well as smaller samples studied.

Our study avoided some defects encountered in previous studies; namely by recruiting a larger sample, including younger age group, as well as studying subjects from different regions within the same country. However, it has its limitations. First, we missed the diagnosis in cataract-operated subjects as we excluded aphakic and pseudophakic patients possibly leading to underestimation of the condition. Second, different governorates were unequally represented. Third, variable examiners' experience could affect the detection of early cases of XFS, in which the subtle signs may be hard to discern or missed altogether.

Our understanding of predisposing factors to XFS is still limited. There is still a universal need for standardized definition and methodological assessment of XFS to allow for the comparison of prevalence studies among diverse populations.

Table 5 Summary of studies on XFS prevalence in the Mediterranean and Middle Eastern countries in patients with agerelated cataract

\begin{tabular}{llcll}
\hline & Country & Sample size $(\boldsymbol{n})$ & Age (years) & Prevalence (\%) \\
\hline Mediterranean & Greece [45] & 2140 & $57-91$ & 27.9 \\
& Portugal [46] & 183 & $70-81$ & 23.9 \\
& Spain [47] & 50 & $68-82$ & 23.9 \\
\multirow{3}{*}{ Middle Eastern } & Turkey [43] & 352 & $57-81$ & 11 \\
& Jordan [44] & 445 & $40-97$ & 10.3 \\
& Saudi Arabia [48] & 681 & $\geq 60$ & 28.19 \\
& Yemen [49] & 2535 & $\geq 40$ & 19.53 \\
\hline
\end{tabular}




\section{ACKNOWLEDGEMENTS}

Funding. No funding or sponsorship was received for this study or publication of this article. The Rapid Service Fee was funded by the authors.

Authorship. All named authors meet the International Committee of Medical Journal Editors (ICMJE) criteria for authorship for this article, take responsibility for the integrity of the work as a whole, and have given their approval for this version to be published.

Authorship Contributions. All authors contributed to the study conception and design. Material preparation, data collection and analysis were performed by Bassem F Aziz, Amr I Elawamry, Maged M Roshdy and Caroline A Tawfik. The first draft of the manuscript was written by Bassem F Riad and Caroline A Tawfik and all authors commented on previous versions of the manuscript. All authors read and approved the final manuscript.

Disclosures. Bassem F Aziz, Amr I Elawamry, Maged M Roshdy and Caroline A Tawfik declare that they have no conflicts of interest.

Compliance with Ethics Guidelines. The research protocol has been submitted to the Ethics Committee of Watany Research and Development Center (WRDC), Cairo, Egypt, and was found to agree with the tenets of the Declaration of Helsinki. The Ethics Committee of WRDC waived the ethical approval and the need to obtain patient consent because of the retrospective nature of the study.

Data Availability. The datasets generated during and/or analyzed during the current study are available from the corresponding author on reasonable request.

Open Access. This article is licensed under a Creative Commons Attribution-NonCommercial 4.0 International License, which permits any non-commercial use, sharing, adaptation, distribution and reproduction in any medium or format, as long as you give appropriate credit to the original author(s) and the source, provide a link to the Creative Commons licence, and indicate if changes were made. The images or other third party material in this article are included in the article's Creative Commons licence, unless indicated otherwise in a credit line to the material. If material is not included in the article's Creative Commons licence and your intended use is not permitted by statutory regulation or exceeds the permitted use, you will need to obtain permission directly from the copyright holder. To view a copy of this licence, visit http://creativecommons.org/licenses/by$\mathrm{nc} / 4.0 /$.

\section{REFERENCES}

1. Ritch R, Schlötzer-Schrehardt U. Exfoliation syndrome. Surv Ophthalmol. 2001;45(4):265-315. https://doi.org/10.1016/S0039-6257(00)00196-X.

2. Tranchina L, Centofanti M, Oddone F, et al. Levels of plasma homocysteine in pseudoexfoliation glaucoma. Graefes Arch Clin Exp Ophthalmol. 2011;249(3):443-8. https://doi.org/10.1007/ s00417-010-1487-6.

3. Djordjevic-Jocic J, Jovanovic P, Bozic M, Tasic A, Rancic Z. Prevalence and early detection of abdominal aortic aneurysm in pseudoexfoliation syndrome and pseudoexfoliation glaucoma. Curr Eye Res. 2012;37(7):617-23. https://doi.org/10. $3109 / 02713683.2012 .665120$.

4. Lindberg JG. Clinical investigations on depigmentation of the pupillary border and translucency of the iris in cases of senile cataract and in normal eyes in elderly persons. Acta Ophthalmol Suppl. 1989;190:1-96.

5. Forsius H. Exfoliation syndrome in various ethnic populations. Acta Ophthalmol Suppl. 1988;66: 71-85.

6. Forsius H, Forsman E, Fellman J, Eriksson AW. Exfoliation syndrome: frequency, gender distribution and association with climatically induced alterations of the cornea and conjunctiva. Acta Ophthalmol Scand. 2002;80(5):478-84. https://doi. org/10.1034/j.1600-0420.2002.800504.

7. Konstas AG, Ringvold A. Epidemiology of exfoliation syndrome. J Glaucoma. 2018;27:4-11. 
8. Krause U, Alanko HI, Kärnä J, et al. Prevalence of exfoliation syndrome in Finland. Acta Ophthalmol. 1988;66:120-2.

9. Åström S, Lindén C. Incidence and prevalence of pseudoexfoliation and open-angle glaucoma in northern Sweden: I. Baseline report. Acta Ophthalmol Scand. 2007;85(8):828-31.

10. Allingham RR, Loftsdottir M, Gottfredsdottir MS, et al. Pseudoexfoliation syndrome in Icelandic families. Br J Ophthalmol. 2001;85(6):702-7.

11. Faulkner HW. Pseudo-exfoliation of the lens among the Navajo Indians. Am J Ophthalmol. 1971;72(1): 206-7. https://doi.org/10.1016/00029394(71)91616-3.

12. Wikipedia.org. Template: Egypt governorates labelled map. 2009-2019. https://en.m.wikipedia. org/wiki/Template:Egypt_governorates_labelled_ map. Updated March 26, 2019. Accessed July 27, 2021.

13. Central Agency for Public Mobilization and Statistics (CAPMAS). Distribution of Egyptian population by age groups. 2017. https://www.capmas.gov.eg/ Pages/StatisticsOracle.aspx?Oracle_id=1966\&page_ id. Updated 2017. Accessed March 28, 2021.

14. Shazly TA, Farrag AN, Kamel A, Al-Hussaini AK. Prevalence of pseudoexfoliation syndrome and pseudoexfoliation glaucoma in Upper Egypt. BMC Ophthalmol. 2011;11(1):1-6. https://doi.org/10. 1186/1471-2415-11-18.

15. Tawfik AA, Hanna ET, Freig SA. Folate status in Egypt. IOSR J Nurs Health Sci. 2014;3(2):32-6.

16. Kang JH, Loomis SJ, Wiggs JL, Willett WC, Pasquale LR. A prospective study of folate, vitamin B6, and vitamin B12 intake in relation to exfoliation glaucoma or suspected exfoliation glaucoma. JAMA Ophthalmol. 2014;132(5):549-59.

17. Pasquale LR, Borrás T, Fingert JH, Wiggs JL, Ritch R. Exfoliation syndrome: assembling the puzzle pieces. Acta Ophthalmol. 2016;94(6):505-12. https:// doi.org/10.1111/aos.12918.

18. Pavičić-Astaloš J, Koluder A, Knežević L, et al. Prevalence of pseudoexfoliation syndrome and pseudoexfoliation glaucoma in population of North-west Croatia aged 40 and over. Acta Clin Croat. 2016;55(3):483-8. https://doi.org/10.20471/ acc.2016.55.03.19.

19. Viso E, Rodríguez-Ares MT, Gude F. Prevalence of pseudoexfoliation syndrome among adult Spanish in the Salnés eye study. Ophthalmic Epidemiol. 2010;17(2):118-24.
20. Kılıç R, Karagöz N, Çetin AB, et al. The prevalence of exfoliation syndrome in Turkey. Acta Ophthalmol. 2016;94(2):105-8.

21. Yildirim N, Yasar E, Gursoy H, Colak E. Prevalence of pseudoexfoliation syndrome and its association with ocular and systemic diseases in Eskisehir, Turkey. Int J Ophthalmol. 2017;10(1):128-34. https://doi.org/10.18240/ijo.2017.01.21.

22. Yalaz M, Othman I, Nas K, et al. The frequency of pseudoexfoliation syndrome in the eastern Mediterranean area of Turkey. Acta Ophthalmol. 1992;70(2):209-13.

23. Kozobolis VP, Papatzanaki M, Vlachonikolis IG, Pallikaris IG, Tsambarlakis IG. Epidemiology of pseudoexfoliation in the island of Crete (Greece). Acta Ophthalmol Scand. 1997;75(6):726-9.

24. Anastasopoulos E, Topouzis F, Wilson MR, et al. Characteristics of pseudoexfoliation in the Thessaloniki Eye Study. J Glaucoma. 2011;20(3):160-6.

25. Stefaniotou M, Petroutsos G, Psilas K. The frequency of pseudoexfoliation in a region of Greece (Epirus). Acta Ophthalmol. 1990;68(3):307-9. https://doi.org/10.1111/j.1755-3768.1990.tb01927. $\mathrm{x}$.

26. Romero-Aroca P, Masip-Serra R, Martínez-Salcedo I, Salvat-Serra M, Fernández-Ballart J, Bautista-Pérez Á. High prevalence of pseudoexfoliation syndrome and its complications in Tarragona in northeast Spain. Eur J Ophthalmol. 2011;21(5):580-8.

27. Montañés JM, Paredes AA, Garcia SC. Prevalence of pseudoexfoliation syndrome in the northwest of Spain. Acta Ophthalmol. 1989;67(4):383-5.

28. Ayed S, Ghorbel M, Nacef L, et al. Le syndrome exfoliatif en Tunisie [The exfoliation syndrome in Tunisia]. Tunis Med. 1990;68(1):19-22.

29. Cumurcu T, Kilic R, Yologlu S. The frequency of pseudoexfoliation syndrome in the middle Black Sea region of Turkey. Eur J Ophthalmol. 2010;20(6): 1007-11. 112067211002000621.

30. Hashemi H, Khabazkhoob M, Emamian MH, Jafari A, Mohazeb-Torabi S, Fotouhi A. The prevalence of exfoliation syndrome in an iranian population aged 45-69 years. Ophthalmic Epidemiol. 2016;23(5): 303-8. https://doi.org/10.3109/09286586.2015. 1132330 .

31. Jammal H, Ameera MA, Al Qudah N, et al. Characteristics of patients with pseudoexfoliation syndrome at a tertiary eye care center in Jordan: a retrospective chart review. Ophthalmol Ther. 2021;10(1):51-61. 
32. Al-Saleh SA, Al-Dabbagh NM, Al-Shamrani SM, et al. Prevalence of ocular pseudoexfoliation syndrome and associated complications in Riyadh, Saudi Arabia. Saudi Med J. 2015;36(1):108-12.

33. Nouri-Mahdavi K, Nosrat N, Sahebghalam R, Jahanmard M. Pseudoexfoliation syndrome in central Iran: a population-based survey. Acta Ophthalmol Scand. 1999;77(5):581-4. https://doi.org/ 10.1034/j.1600-0420.1999.770521.x.

34. Al-Saffar AA. A clinical survey of pseudoexfoliation syndrome in Sulaimaniya city-Kurdistan Iraq. Saudi J Med Pharm Sci. 2017;3:1111-7.

35. Bamashmus M. Prevalence of pseudoexfoliation syndrome in Yemen-hospital based study. J Arab Board Heal Spec. 2009;10(4):10-4.

36. Stein JD, Pasquale LR, Talwar N. Geographic and climatic factors associated with exfoliation syndrome. Arch Ophthalmol. 2011;129(8):1053-60.

37. Arnarsson A, Damji KF, Sverrisson T, Sasaki H, Jonasson F. Pseudoexfoliation in the Reykjavik Eye Study: prevalence and related ophthalmological variables. Acta Ophthalmol Scand. 2007;85(8): 822-7.

38. Rouhiainen $H$, Teräsvirta $M$. Presence of pseudoexfoliation on clear and opacified crystalline lenses in an aged population. Ophthalmologica. 1992;204(2):67-70. https://doi.org/10.1159/ 000310271 .

39. Sainz Gómez C, Moreno-Montañés J, Escudero Berasategui JM, Sádaba Echarri LM, Fernández Hortelano A, García LA. Prevalencia y factores de riesgo del síndrome pseudoexfoliativo en una población institucionalizada en Navarra [Prevalence and risk factors of pseudoexfoliation syndrome in institutionalized geriatric patients in Navarra]. Arch Soc Esp Oftalmol. 2003;78(7):383-8.

40. Jones W, White RE, Magnus DE. Increased occurrence of exfoliation in the male, Spanish American population of New Mexico. J Am Optom Assoc. 1992;63(9):643-8.

41. McCarty CA, Taylor HR. Pseudoexfoliation syndrome in Australian adults. Am J Ophthalmol.
2000;129(5):629-33. S0002-9394(99)00466-3.

https://doi.org/10.1016/

42. Schlötzer-Schrehardt U, Naumann GOH. Ocular and systemic pseudoexfoliation syndrome. Am J Ophthalmol. 2006;141(5):921-37. https://doi.org/ 10.1016/j.ajo.2006.01.047.

43. Gunes A, Yasar C, Tok L, Tok O. Prevalence of pseudoexfoliation syndrome in Turkish patients with senile cataract. Semin Ophthalmol. 2017;32(3):297-301. https://doi.org/10.3109/ 08820538.2015 .1068344 .

44. Shihadeh WA, Jammal HM, Alkhatib SQ, et al. Prevalence of exfoliation syndrome in patients scheduled for cataract surgery: a hospital-based study in Northern Jordan. Jordan Med J. 2012;46(3):216-20.

45. Andrikopoulos GK, Mela EK, Georgakopoulos CD, et al. Pseudoexfoliation syndrome prevalence in Greek patients with cataract and its association to glaucoma and coronary artery disease. Eye (Lond). 2009;23(2):442-7. https://doi.org/10.1038/sj.eye. 6702992.

46. Alfaiate M, Leite E, Mira J, Cunha-Vaz JG. Prevalence and surgical complications of pseudoexfoliation syndrome in Portuguese patients with senile cataract. J Cataract Refract Surg. 1996;22(7):972-6. https://doi.org/10.1016/s0886-3350(96)80202-1.

47. Vazquez-Ferreiro P, Carrera-Hueso FJ, Barreiro-Rodriguez L, Diaz-Rey M, Jornet JEP. Prevalence of cataract complications in patients with pseudoexfoliation syndrome in Northwestern Spain. Arq Bras Oftalmol. 2019;82(6):495-500. https://doi.org/10. 5935/0004-2749.20190095.

48. Gabr AF. Pseudoexfoliation cataract: possible systemic associations. Delta J Ophthalmol. 2016;17: 133-6.

49. Al-Shaer M, Bamashmus M, Al-Barrag A. Point prevalence of pseudoexfoliation syndrome in patients scheduled for cataract surgery in eye camps in Yemen. Middle East Afr J Ophthalmol. 2010;17: 64-7. 